\title{
Performance Characteristics of Hot-dip and Plasma Spray Aluminide Coated Nickel-Based Superalloy 718 under Cyclic Oxidation in Water Vapour
}

\author{
Pius Kibet KOECH *, Chaur Jeng WANG
}

Department of Mechanical Engineering, National Taiwan University of Science and Technology, No. 43 Keelung Road, Section 4, Taipei 10672, Taiwan, ROC

crossref http://dx.doi.org/10.5755/j01.ms.25.4.21334

Received 15 August 2018; accepted 12 October 2018

\begin{abstract}
Aluminium coating due to its ability to form stable alumina oxide scale are commonly used to protect materials such as inconel 718 superalloys at high operational temperatures. Relevant properties of the oxide scale formed; growth rate and coating adherence is not only determined by the composition of the coating material used but is also influenced by the coating manufacturing process and the test condition. In the present work, effect of water vapour and thermocycling commonly prevailing on the morphology and composition of the alumina scales formed during high temperature oxidation was studied using hot-dip and plasma spray aluminium coatings. The coatings highly improved oxidation resistance of the alloy substrate with hot dip coating showing the lowest mass change compared to plasma spray. The results also show that the hot-dip coating has an inherently different morphology and growth rate compared to those formed on the plasma spray coating. High rate of oxidation, spallation and large voids with little protective alumina oxide layer were observed in moist condition test especially in plasma spray coatings.

Keywords: IN 718, hot-dip, plasma spray, aluminium coating, water vapour.
\end{abstract}

\section{INTRODUCTION}

Nickel based inconel (IN) 718 superalloy is widely used in aerospace, nuclear, chemical and tooling industry due to its excellent tensile strength, impact strength, creep resistance, oxidation and corrosion resistance at extremely high application temperatures [1-4]. Solid solution and precipitation hardening are two main mechanisms known for strengthening of nickel-based superalloys [5]. IN 718 is thus a precipitation strengthened nickel-based austenite superalloy where the particles $\left.\gamma^{\prime}\left(\mathrm{Ni}_{3} \mathrm{Al}\right)\right)$ and $\gamma^{\prime \prime}\left(\mathrm{Ni}_{3} \mathrm{Nb}\right)$ both precipitates simultaneously or sequentially above $550{ }^{\circ} \mathrm{C}$, depending on the chemical compositions of $\mathrm{Ti}, \mathrm{Al}$ and $\mathrm{Nb}[6,7]$. Common phenomenon reported is that $\gamma^{\prime}$ precipitates out first from $\gamma$ - matrix, then $\gamma^{\prime \prime}$ phase nucleates heterogeneously at the $\gamma^{\prime} / \gamma$ interface and tends to merge with $\gamma^{\prime}$ particles creating a $\gamma^{\prime} / \gamma^{\prime \prime}$ co-precipitates $[8,9]$. When exposed to temperatures above $650{ }^{\circ} \mathrm{C}$, the metastable $\gamma^{\prime \prime}$ particle transforms to the detrimental stable $\delta$ phase which precipitates at the grain boundaries. Studies shows that $\alpha-\mathrm{Cr}$ also forms in addition to delta $\delta$ phase and is attributed to the depletion of $\mathrm{Ni}$ and an enrichment of $\mathrm{Cr}$ as a result of $\mathrm{Cr}$ rejection during delta $\delta$ phase formation. However high content of $\mathrm{Cr}$ leads to the reduction of creep strength. The $\delta$ - phase which is a major phase in such high temperatures is also attributed to loss of mechanical properties such as ductility, creep resistance and hardness $[10-13]$.

IN 718 develops chromia protective oxide layer when exposed to high temperature oxidizing conditions. However, such protective oxide is susceptible to cracking and subsequent spallation leading to breakaway oxidation especially under thermal cycling condition. With prolonged oxidation at high temperatures, aluminum is found to precipitate as an internal oxide beneath the chromium oxide scale. Other elements such as manganese which is found to be incorporated into the scale as $\mathrm{MnCr}_{2} \mathrm{O}_{4}$ is reported to improve oxide adherence as well as reducing chromium evaporation rate by lowering vapour pressure of $\mathrm{CrO}_{3}$ [14]. Titanium just like aluminum has got high affinity of oxygen and thus have a strong tendency to form an oxide. Formations of $\mathrm{NiCr}_{2} \mathrm{O}_{4}$ and $\mathrm{NiFe}_{2} \mathrm{O}_{4}$ spinels are however reported to increase the Pilling-Bedworth ratio for $\mathrm{Cr}$ oxidation which contributes to lateral spallation of oxide scale [15].

The efforts to improve temperature stability of IN 718 has been going on with main focus on surface modification. Several surface modifications techniques are categorized as either surface treatments or surface coatings. Electropolishing, heat treatment, shot peening, sandblasting, laser or chemical passivation are some of the surface treatments commonly carried out whose aim is to have energy stored on the surface region of the material in form of dislocations. Some of the surface coatings employed are cladding, sputtering, ion-implantation, pack cementation, micro-arc oxidation, thermal spray and hot-dip coating among others [16-19]. Surface coatings mainly thermal-spray and hotdip coatings have recently found increasing use especially for high-temperature engineering applications due to their affordability and ease of use even in complex parts. Furthermore, they have added advantages such as time effectiveness, short processing time, flexibility among others. Aluminum is the consumable material commonly used for surface coatings during hot-dip or plasma spray due

\footnotetext{
* Corresponding author. Tel.: +886-963-544-340;

E-mail address: d10303809@mail.ntust.edu.tw (P.K. Koech)
} 
to its ability to form a stable alumina oxide scale $[15,20]$. This article therefore is aimed to study the performance of hot-dip and plasma spray aluminium coatings under cyclic oxidation in dry and in moist vapour condition.

\section{EXPERIMENTAL DETAILS}

\subsection{Sample preparation}

Nickel based IN 718 superalloy specimens of chemical composition shown in Table 1 were sectioned to rectangular sizes of $15 \mathrm{~mm} \times 15 \mathrm{~mm} \times 2 \mathrm{~mm}$ using water-cooled abrasive cut-off wheel. Specimens were mechanically ground to 800 grit $\mathrm{SiC}$ papers then holes of about $1.5 \mathrm{~mm}$ in diameter were drilled for suspension during hot-dip coating.

Table 1. Chemical composition of Inconel 718 used in this research

\begin{tabular}{|c|c|c|c|c|c|c|c|c|}
\hline Element & $\mathrm{Ni}$ & $\mathrm{Cr}$ & $\mathrm{Fe}$ & $\mathrm{Ti}$ & $\mathrm{Si}$ & $\mathrm{Al}$ & $\mathrm{Nb}$ & $\mathrm{Mo}$ \\
\hline wt.\% & Bal. & 18.46 & 17.82 & 1.07 & 0.38 & 0.46 & 5.52 & 2.83 \\
\hline at.\% & Bal. & 20.58 & 18.66 & 0.82 & 0.46 & 0.71 & 3.65 & 1.73 \\
\hline
\end{tabular}

\subsection{Specimen coating}

All abraded and polished specimens were degreased ultrasonically in acetone for five minutes, then cleaned in a solution of 10 wt. $\% \mathrm{NaOH}$ and 15 vol.\% $\mathrm{H}_{3} \mathrm{PO}_{4}$ for 15 seconds and finally rinsed in fresh water, ethanol and dried. After cleaning, flux coated specimens were immersed into a molten bath of pure aluminum (99.5 wt.\% Al) maintained at $700{ }^{\circ} \mathrm{C}$ for only one minute. Immersion and removal speed from molten bath was $15 \mathrm{~cm} / \mathrm{min}$. Aluminized hot-dipped specimens were then cleaned to remove oxide flux attached to the surface using solution of nitric, phosphoric acid and water in a 1:1:1 volume ratio at $25{ }^{\circ} \mathrm{C}$, then finally rinsed in fresh water, ethanol and dried. Commercially pure aluminum $(99.5 \mathrm{wt} \% \mathrm{Al})$ was used as a spray consumable to create a coating on sand blasted and ultrasonically cleaned surfaces of IN 718 specimens for plasma spray coatings. Gas flow rate of $4.2 \mathrm{~m}^{3} / \mathrm{h}$ at $5500{ }^{\circ} \mathrm{C}$ with particle velocity of $240 \mathrm{~m} / \mathrm{s}$ and spray rate of $2.5 \mathrm{~kg} / \mathrm{h}$ were used.

\subsection{Oxidation test}

Bare and aluminium coated IN 718 specimens were cyclically oxidized inside a horizontal tube furnace at 650 and $750{ }^{\circ} \mathrm{C}$ in both dry air and moist air by passing dry carrier gas to the hot chamber zone at a flow rate of $200 \mathrm{cc} / \mathrm{min}$ maintained at $1 \mathrm{~atm}$. For cyclic oxidation under water vapour condition, moist air was supplied to oxidation zone by passing dry carrier gas through hot water bath kept at $76{ }^{\circ} \mathrm{C}$ with vapour prsseure of about $0.397 \mathrm{~atm}$. The specimen exposure time was 10 hours in hot chamber and 30 minutes in room temperature a cycle for up to 90 hours (9 cycles) in hot chamber. Specimens were picked after each cycle for average mass change measurements using precision electron balance (Mettler Toledo) with an accuracy of $0.1 \mathrm{mg}$ so as to assess high-temperature performance of the aluminium coatings on IN 718 alloy.

\subsection{Cross-sectional and surface morphology characterization}

Characterization of the surface morphology and crosssectional microstructure were carried out using JEOL JSM-
6390 scanning electron microscopy (SEM), while the distributions of elements in various solid phases were analyzed using an energy dispersive X-ray spectroscopy (EDS) and electron probe microanalysis (EPMA). Phase analysis of oxidation scales and corrosion products on surfaces of the bare and aluminized coated specimens were conducted using Bruker D2-Phaser X-ray diffraction (XRD) machine with a range of $20^{\circ} \leq 2 \theta \leq 80^{\circ}$ diffraction angle at steps of $0.02 /$ step. Diffraction patterns from XRD data were analyzed using DIFFRAC.EVA software.

\section{RESULTS}

\subsection{As-deposited aluminium coating specimens}

Cross-sectional micrograph, surface morphology and XRD patterns of as coated aluminized hot-dip and plasma spray alloy specimens are given in Fig. 1 .
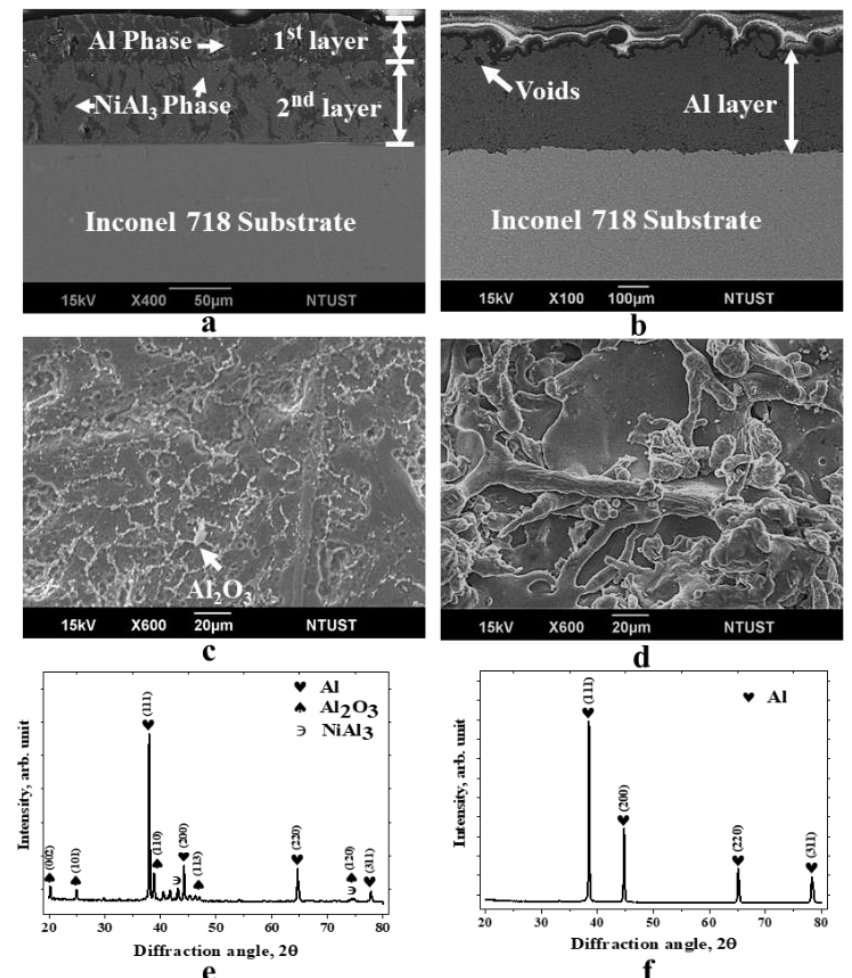

Fig. 1. Cross-sectional micrograph, SEM surface morphology and XRD pattern of as coated aluminized alloy IN 718: a, c, e-hot-dip; b, d, f-plasma spray specimens respectively

The coating on the hot-dip specimen adhered firmly to the IN 718 substrate with no signs of cracks, porosities or delamination as seen in the cross-sectional micrograph of Fig. 1 a. The $1^{\text {st }}$ layer on top of the coating comprise of a dark-grey compact aluminum phase with a thickness of approximately $30 \mu \mathrm{m}$. The $2^{\text {nd }}$ layer consists of light-grey $\mathrm{NiAl}_{3}$ phase with a thickness of about $60 \mu \mathrm{m}$ formed at the interface between the substrate and the aluminum layer. The amount and depth of the inter-diffusion phases formed were determined by the hot-dip duration, the activity of molten aluminum on the outer zone of the coating and the activities of nickel among other minor elements on the substrate side. The cross-sectional micrograph for plasma spray coating in Fig. $1 \mathrm{~b}$ shows that only one layer of aluminum coating formed on top of the substrate. The aluminum coating layer 
formed consists of deposited splats with presence of some $\mathrm{Al}_{2} \mathrm{O}_{3}$ oxides and voids ingrained at the grain boundaries of the deposited splats. Surface morphology of as-coated hotdip specimen consists of aluminium grains as in Fig. $1 \mathrm{c}$. The grains contain oxides of $\mathrm{Al}_{2} \mathrm{O}_{3}$ on the ridges while the crater region and entire surface is mainly made of aluminum layer with presence of some intermetallic phases of $\mathrm{NiAl}_{3}$ as determined by EDS analysis. The X-ray diffraction (XRD) analysis of as-coated hot-dip specimen depicted in Fig. 1 e also indicates that the surface structure consists mainly of aluminum layer with some peaks of $\mathrm{Al}_{2} \mathrm{O}_{3}$ and $\mathrm{NiAl}_{3}$.

The surface morphology for plasma spray coating shown in Fig. $1 \mathrm{~d}$ consists of irregular grain boundaries with existence of some voids and pores. Both EDS analysis and XRD pattern results given in Fig. $1 \mathrm{f}$ indicates that surface morphology of plasma spray coating consists mainly of aluminum layer.

\subsection{Kinetics of oxidation}

The kinetics of cyclic oxidation curves for bare IN 718 superalloy and aluminized coatings done in dry and moist air at $650{ }^{\circ} \mathrm{C}$ and $750{ }^{\circ} \mathrm{C}$ respectively are given in Fig. 2 . The mass changes during thermal cycling of all tested specimens both in dry and moist air indicates that the rate of oxidation increased with both the duration and exposure temperature. The mass gain for uncoated specimens in dry air exhibited highest rate of oxidation. The mass changes in all conditions and temperatures are higher during the early stages of oxidation but changes to steady state with increased exposure time. During early stages of oxidation, rapid formation and growth of protective oxide scale inhibits inward diffusion of oxygen and outward diffusion of alloy ions. It is also evident that both the hot-dip and plasma-sprayed coatings improved oxidation resistance of the alloy. In terms of mass changes, no significant difference in performance of the two different aluminum coatings namely hot-dip and plasma-spray was observed compared to bare substrate. However, hot-dip coatings with the lowest mass change demonstrated that it is slightly much better than plasma-sprayed coatings in improving the oxidation resistance of the alloy. Oxidation rate for both aluminum coatings are slightly higher in moist vapor condition both at $650{ }^{\circ} \mathrm{C}$ and $750{ }^{\circ} \mathrm{C}$. The mass change curves in moist vapour also shows undulated nature after about 40 to $50 \mathrm{hrs}$ which suggests that spallation of oxide scale and re-oxidation took place. Both the bare and coated specimens in all conditions follow a parabolic rate law. The difference between the bare alloy and aluminum coated specimens could be attributed to the ability of the later to re-heal after oxide spallation due formation of a protective alumina scale.

\subsection{Surface morphology and cross-sectional micrograph of hot-dip coatings}

Surface morphology of the oxide scale formed on aluminized hot-dip specimens at 650 and $750{ }^{\circ} \mathrm{C}$ are given in Fig. 3. The EDS analysis infer that the surface of the coating consists mainly of $\mathrm{Al}_{2} \mathrm{O}_{3}$ oxide after 90 hrs in dry air at $650{ }^{\circ} \mathrm{C}$ for Fig. 3 a. Specimens oxidized in dry air at $750{ }^{\circ} \mathrm{C}$ indicates some scale spallation after $10 \mathrm{hrs}$ as shown in Fig. 3 b. The surface comprises of $\mathrm{Al}_{2} \mathrm{O}_{3}$ scale while the area under spallation is an exposed aluminum layer.
Analysis of such spalled portion does not show any evidence of oxide reformation during the $10 \mathrm{hrs}$ isothermal oxidation an indication that spallation took place during cooling of the specimen. Scale spallation, oxide-reformation and regrowth of aluminum-oxide nodules increased with cyclic oxidation shown in Fig. $3 \mathrm{c}$ after $90 \mathrm{hrs}$ at $750{ }^{\circ} \mathrm{C}$. Besides spallation and oxide reformation, EDS analysis confirms presence of $\mathrm{Al}_{1.98} \mathrm{Cr}_{0.02} \mathrm{O}_{3}$ in addition to $\mathrm{Al}_{2} \mathrm{O}_{3}$ oxides indicating outward diffusion of chromium and other substrate elements with increased exposure time and temperature. Other phases detected in small amounts are $\mathrm{NiAl}_{3}, \mathrm{Ni}_{2} \mathrm{Al}_{3}$ with oxides of $\mathrm{NiO}$ and $\mathrm{NiAl}_{2} \mathrm{O}_{4}$.

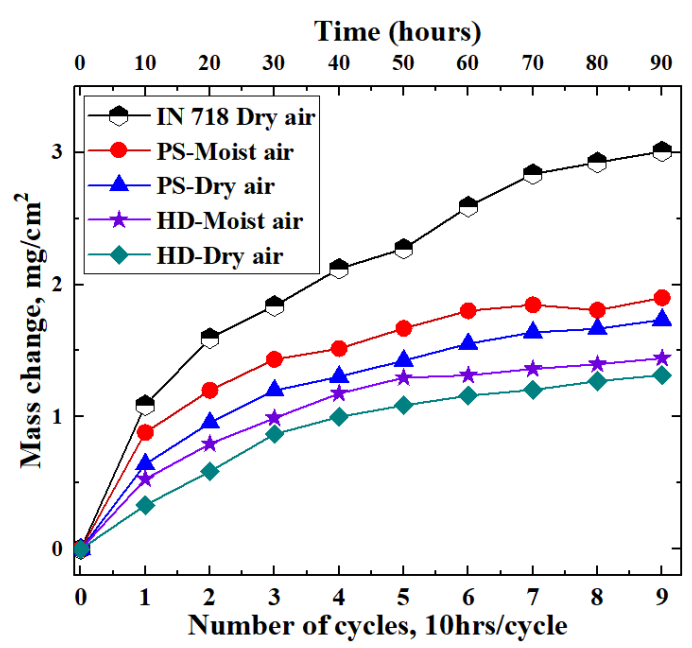

a

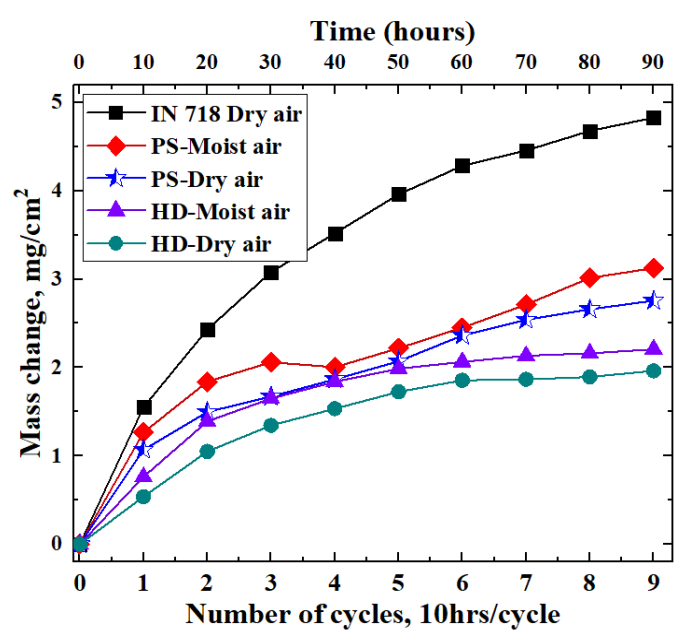

b

Fig. 2. Mass changes of bare IN 718, hot-dip and plasma spray coated specimens during $90 \mathrm{hrs}$ cyclic oxidation in dry and moist air at: $\mathrm{a}-650^{\circ} \mathrm{C} ; \mathrm{b}-750^{\circ} \mathrm{C}$

Oxide spallation and existence of some cracks were observed after $90 \mathrm{hrs}$ for specimens oxidized in moist air at $650{ }^{\circ} \mathrm{C}$ as shown in Fig. $3 \mathrm{~d}$. The oxide scale composed mainly $\mathrm{Al}_{2} \mathrm{O}_{3}$ with minor elements of nickel indicating presence of $\mathrm{NiAl}_{3}$ phases. However, hot-dip specimens exposed to high-temperature at $750{ }^{\circ} \mathrm{C}$ after $10 \mathrm{hrs}$ in moist air experienced high spallation and surface cracking as shown in Fig. 3 e. EDS analysis did not show any signs of scale reformations on the debonded sections indicating that scale spallation took place only during specimen cooling and not during isothermal high-temperature exposure. 
Oxide scale spallation and voids increased with cyclic oxidation in moist condition after $90 \mathrm{hrs}$ at $750{ }^{\circ} \mathrm{C}$ as shown in Fig. $3 \mathrm{f}$. Oxide reformation seems to reduce in moist air compared to those in dry condition. Porous plate-like spinel of $\mathrm{NiAl}_{2} \mathrm{O}_{4}$ was also detected on the surface as shown in the enlarged portion of Fig. $3 \mathrm{f}$. Other minor oxides detected were $\mathrm{Al}_{1.98} \mathrm{Cr}_{0.02} \mathrm{O}_{3}, \mathrm{Fe}_{2} \mathrm{O}_{3}, \mathrm{NiO}, \mathrm{NiFe}_{2} \mathrm{O}_{4}$ and $\mathrm{FeCr}_{2} \mathrm{O}_{4}$.
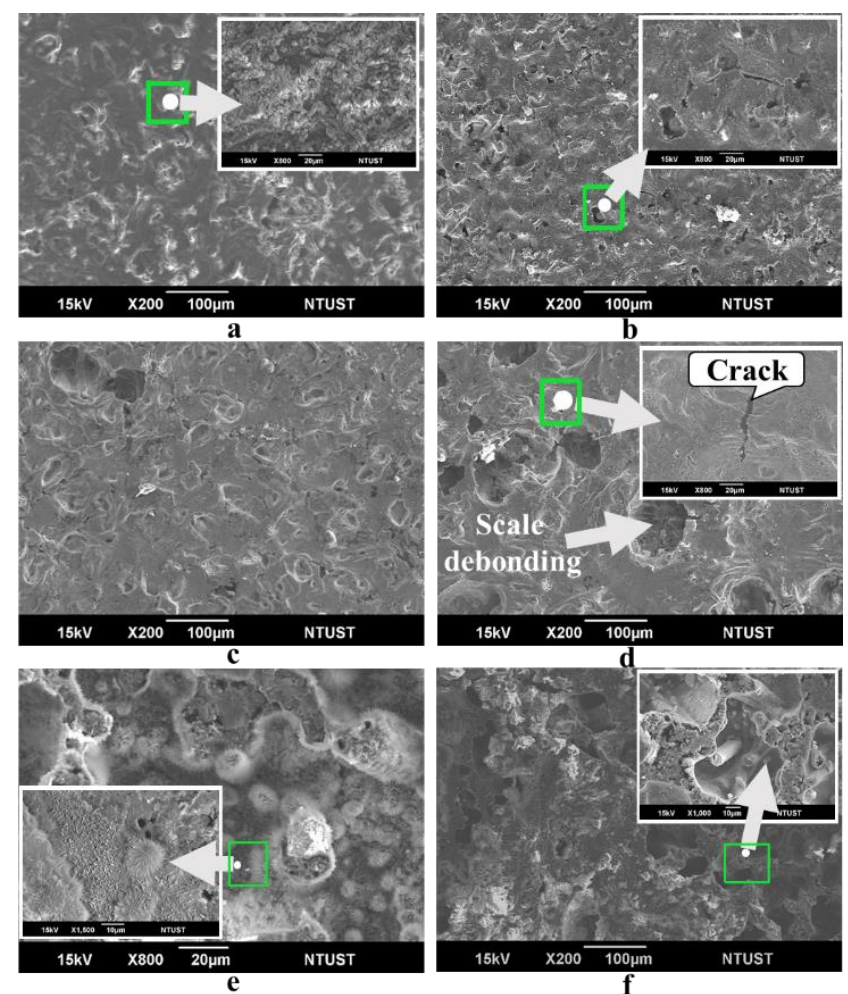

Fig. 3. SEM surface morphology of hot-dip specimens oxidized in dry air at: $\mathrm{a}-650{ }^{\circ} \mathrm{C}$ for $90 \mathrm{hrs} ; \mathrm{b}-750{ }^{\circ} \mathrm{C}$ for $10 \mathrm{hrs}$; $\mathrm{c}-750{ }^{\circ} \mathrm{C}$ for $90 \mathrm{hrs}$, and in moist air at: $\mathrm{d}-650{ }^{\circ} \mathrm{C}$ for $90 \mathrm{hrs}$; $\mathrm{e}-750{ }^{\circ} \mathrm{C}$ for $10 \mathrm{hrs} ; \mathrm{f}-750{ }^{\circ} \mathrm{C}$ for $90 \mathrm{hrs}$

Cross-sectional micrographs of hot-dip aluminized IN 718 specimens after high-temperature exposure in dry and moist air are given in Fig. 4. Aluminium coating layer transformed into various distinct layers. A thin layer of $\mathrm{Al}_{2} \mathrm{O}_{3}$ oxide scale formed on the surface of the aluminide coating while an aluminum layer formed beneath it after $90 \mathrm{hrs}$ in dry air at $650{ }^{\circ} \mathrm{C}$ as shown in Fig. 4 a. A layer comprising of $\mathrm{NiAl}_{3}$ phase formed in the middle while $\mathrm{Ni}_{2} \mathrm{Al}_{3}$ is next to the substrate. The coating layers does not show any signs of porosities or delamination. However, specimens exposed to high-temperature at $750{ }^{\circ} \mathrm{C}$ after $10 \mathrm{hrs}$ in dry air given in Fig. $4 \mathrm{~b}$ indicates formations of voids within the aluminum layer. $A$ thin layer of $\mathrm{Ni}_{2} \mathrm{Al}_{3}$ is seen to have formed at the interface between the substrate and the $\mathrm{NiAl}_{3}$ phase as determined by EDS analysis. With increased oxidation time, voids are seen to extend to $\mathrm{NiAl}_{3}$ layer after $90 \mathrm{hrs}$ in dry air at $750{ }^{\circ} \mathrm{C}$ as shown in Fig. $4 \mathrm{c}$. The $\mathrm{Ni}_{2} \mathrm{Al}_{3}$ layer increased with cyclic oxidation and temperature while the aluminum layer and $\mathrm{NiAl}_{3}$ gets depleted with increased voids. Depletion of aluminum could be attributed to inward diffusion to enhance formation of $\mathrm{NiAl}$ intermetallic layers and outward diffusion for the reformation of aluminum oxide layer. Fig. $4 \mathrm{~d}$ for hot-dip specimen oxidized in moist air at $650{ }^{\circ} \mathrm{C}$ after $90 \mathrm{hrs}$ unlike in dry air shows presence of voids highly dispersed within the aluminum layer with fragmented and reduced thickness of $\mathrm{Al}_{2} \mathrm{O}_{3}$ scale. Thickness of $\mathrm{Ni}_{2} \mathrm{Al}_{3}$ intermetallic layer and number of voids observed in Fig. $4 \mathrm{e}$ after $10 \mathrm{hrs}$ and Fig. $4 \mathrm{f}$ after $90 \mathrm{hrs}$ increased with exposure time while the aluminum layer gets depleted for specimens exposed to moist air at $750{ }^{\circ} \mathrm{C}$. Cracks are also seen to form at the interface of $\mathrm{Al}$ layer and the $\mathrm{NiAl}_{3}$ phase after $90 \mathrm{hrs}$ as observed in Fig. $4 \mathrm{f}$. The elemental compositions of $\mathrm{Al}, \mathrm{Ni}$, $\mathrm{Cr}$ and Fe along the $\mathrm{Y}-\mathrm{Y}$ axis of Fig. $4 \mathrm{~d}$ and $\mathrm{f}$ is given in Fig. $5 \mathrm{a}$ and $\mathrm{b}$ respectively. The inward diffusion of $\mathrm{Al}$ and outward diffusion of $\mathrm{Ni}, \mathrm{Cr}$ and $\mathrm{Fe}$ among other elements contributes to the growth of such observed $\mathrm{NiAl}$ intermetallic layers.
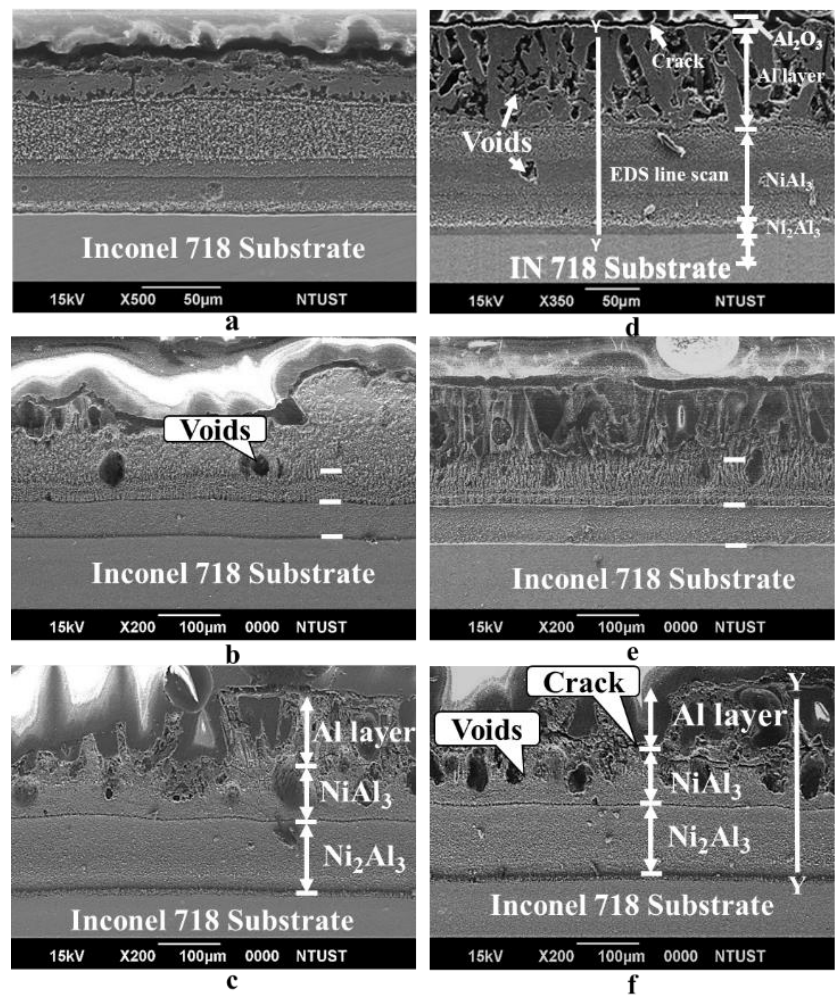

Fig. 4. Cross-sectional micrographs of hot-dipped specimens oxidized in dry air at: $\mathrm{a}-650{ }^{\circ} \mathrm{C}$ for $90 \mathrm{hrs} ; \mathrm{b}-750{ }^{\circ} \mathrm{C}$ for $10 \mathrm{hrs} ; \mathrm{c}-750{ }^{\circ} \mathrm{C}$ for $90 \mathrm{hrs}$, and in moist air at $\mathrm{d}-650^{\circ} \mathrm{C}$ for $90 \mathrm{hrs} ; \mathrm{e}-750{ }^{\circ} \mathrm{C}$ for $10 \mathrm{hrs} ; \mathrm{f}-750^{\circ} \mathrm{C}$ for $90-\mathrm{hrs}$

\subsection{Effect of plasma spray coatings on the high temperature cyclic oxidation}

Fig. 6 shows the surface morphology that developed on the plasma spray coated IN 718 alloy specimens after various durations of cyclic oxidation in dry and moist air at 650 and $750{ }^{\circ} \mathrm{C}$. Unlike in hot-dip coating specimens given in Fig. 3, surface morphology of plasma spray has got irregular grain shapes with grooves along the splat boundaries. The oxide scale consists of $\mathrm{Al}_{2} \mathrm{O}_{3}$ with porosity's along the lower portion of the ridges as shown in Fig. 6 a after $90 \mathrm{hrs}$ in dry air at $650^{\circ} \mathrm{C}$. Cracks and aluminum depletion on the surface seems to increase with exposure time as observed in Fig. $6 \mathrm{~b}$ after $10 \mathrm{hrs}$ compared to Fig. $6 \mathrm{c}$ after $90 \mathrm{hrs}$ in dry air at $750{ }^{\circ} \mathrm{C}$. EDS analysis indicates that besides $\mathrm{Al}_{2} \mathrm{O}_{3}$, other elements such as $\mathrm{Ni}, \mathrm{Cr}$ and $\mathrm{Fe}$ were detected on the surface due to outward diffusion of substrate elements towards the surface of the coating. At points indicated by letters ' $A$ ', 'B' and ' $C$ ' in 
Fig. 6 c, oxides of $\mathrm{Al}_{2} \mathrm{O}_{3}, \mathrm{NiO}$ and spinels of $\mathrm{NiAl}_{2} \mathrm{O}_{4}$ formed on the surface after $90 \mathrm{hrs}$. Corresponding chemical compositions of the points indicated are given in Table 2.
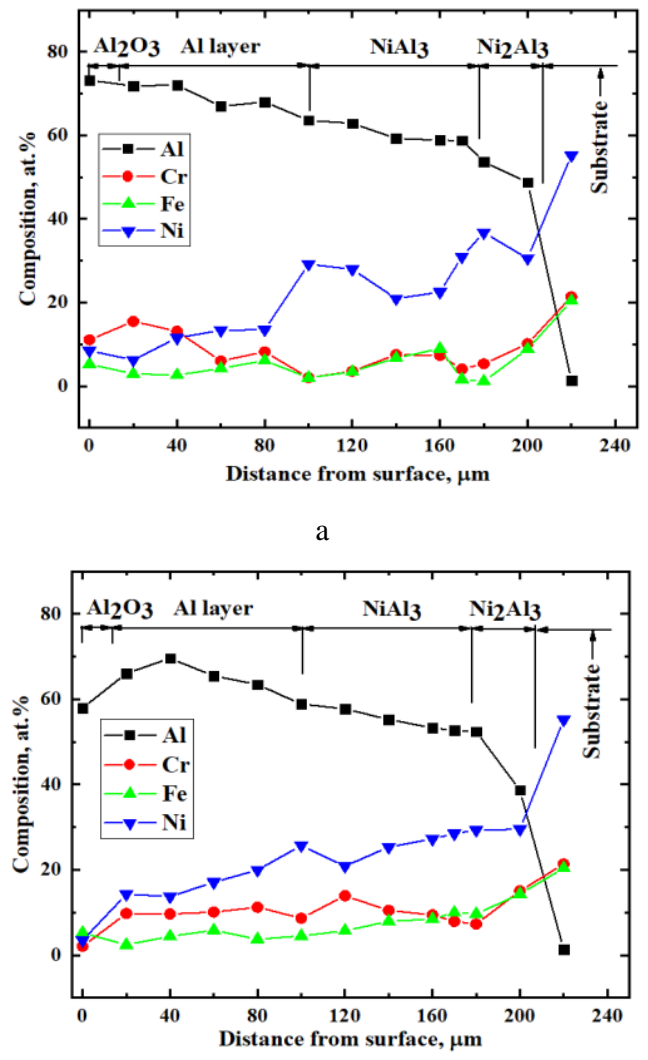

b

Fig. 5. EDS results for elemental compositions $\mathrm{Al}, \mathrm{Cr}, \mathrm{Fe}$ and $\mathrm{Ni}$ across the coating layer axis (Y-Y) after $90 \mathrm{hrs}$ in moist air for: a-Fig. 4 d at $650{ }^{\circ} \mathrm{C}$; b-Fig. 4 f at $750{ }^{\circ} \mathrm{C}$

Surface morphology of specimens oxidized in moist air for $90 \mathrm{hrs}$ at $650{ }^{\circ} \mathrm{C}$ given in Fig. $6 \mathrm{~d}$, after $10 \mathrm{hrs}$ at $750{ }^{\circ} \mathrm{C}$ shown in Fig. 6 e and after 90 hrs at $750{ }^{\circ} \mathrm{C}$ in Fig. 6 f shows raised oxide nodular of $\mathrm{Al}_{2} \mathrm{O}_{3}$ with deep furrows and ridges appearing along the splat boundaries. Furrows and cracks are seen to be more profound compared to those in dry air and increases with exposure time indicating that splat boundaries are more susceptible to moist oxidation attack. Water vapour trapped at the furrows weakens the bonding at the splat boundaries inducing more cracks as shown. Increased cracks and furrows facilitates high rate of oxidation due to increased surface area. The surface of the coating at the point indicated by letter ' $\mathrm{D}$ ' in Fig. $6 \mathrm{f}$, consists of $\mathrm{Al}_{2} \mathrm{O}_{3}$ oxide while at the furrow like portion indicated by letter ' $\mathrm{E}$ ' shows that besides $\mathrm{Al}_{2} \mathrm{O}_{3}$, minor oxides of $\mathrm{Al}_{1.98} \mathrm{Cr}_{0.02} \mathrm{O}_{4}, \mathrm{NiO}$ or $\mathrm{NiAl}_{2} \mathrm{O}_{4}$ spinels could have formed. Chemical compositions indicated at points ' $\mathrm{D}$ ' and 'E' are given in Table 2.

Table 2. Chemical composition (at.\%) of points indicated in Fig. 6 by EDS analysis

\begin{tabular}{|c|c|c|c|c|c|}
\hline Position & $\mathrm{Al}$ & $\mathrm{Cr}$ & $\mathrm{Ni}$ & $\mathrm{Fe}$ & $\mathrm{O}$ \\
\hline $\mathrm{A}$ & 55.32 & - & 8.29 & - & 36.39 \\
\hline $\mathrm{B}$ & 53.98 & - & 18.62 & - & 27.41 \\
\hline $\mathrm{C}$ & 53.12 & - & 15.95 & - & 30.93 \\
\hline $\mathrm{D}$ & 50.01 & - & - & - & 49.99 \\
\hline $\mathrm{E}$ & 54.89 & 2.86 & 9.96 & 1.99 & 30.29 \\
\hline
\end{tabular}

Cross-sectional micrographs of aluminized plasma spray coated specimens exposed to high temperature oxidation in dry and moist air at various durations are given in Fig. 7. After 90 hrs in dry air at $650{ }^{\circ} \mathrm{C}$ shown in Fig. 7 a, voids are observed at the $\mathrm{Al}$ coating layer with micro cracks between $\mathrm{Al}_{2} \mathrm{O}_{3}$ oxide layer and the aluminum coating. However, in moist air as in Fig. $7 \mathrm{~d}$, aluminum layer is separated from the $\mathrm{NiAl}_{3}$ intermetallic layer by a crack with diminished oxide layer. For specimens oxidized at $750{ }^{\circ} \mathrm{C}$, thin and compact layers of $\mathrm{NiAl}$ - intermetallics had formed after 10 hrs in dry air with some voids observed within the aluminum layer as observed in Fig. 7(b). However, in moist air after 10 hrs shown in Fig. 7(e), the voids have extended to the $\mathrm{NiAl}_{3}$ intermetallic layer with high flaking of the oxide scale.
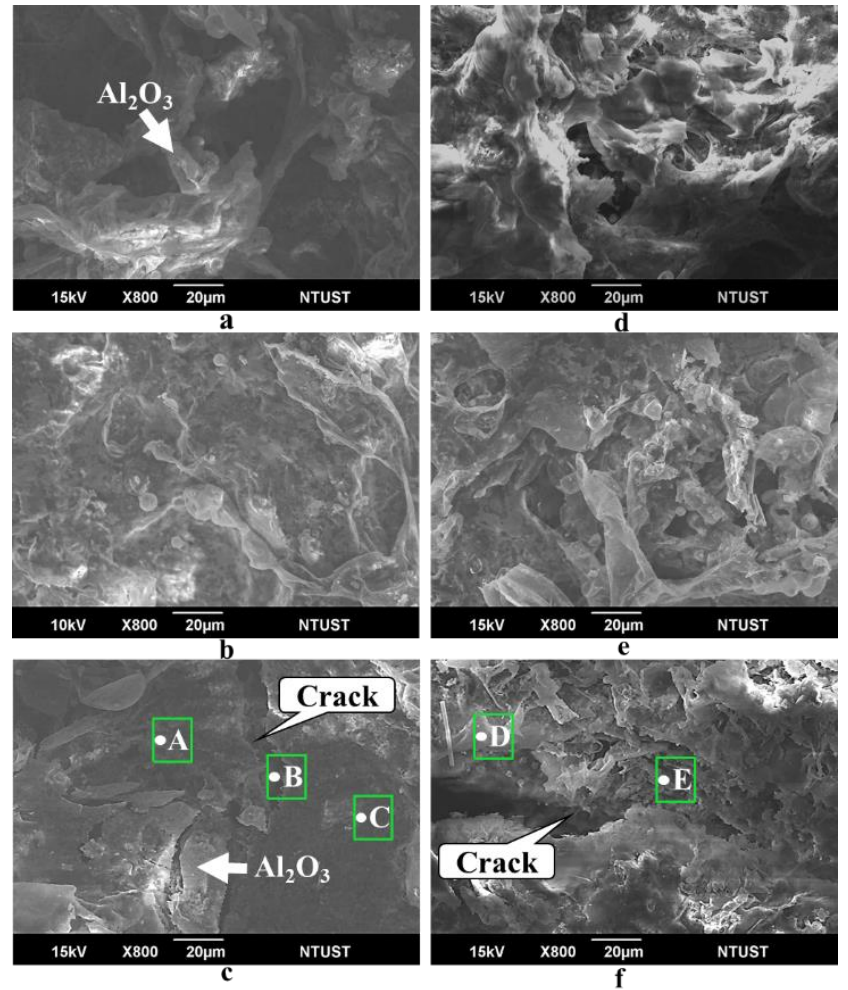

Fig. 6. SEM surface morphology of plasma spray specimens oxidized in dry air at: $\mathrm{a}-650^{\circ} \mathrm{C}$ for $90 \mathrm{hrs}$; b $-750{ }^{\circ} \mathrm{C}$ for $10 \mathrm{hrs} ; \mathrm{c}-750^{\circ} \mathrm{C}$ for $90 \mathrm{hrs}$, and in moist air at: $\mathrm{d}-650^{\circ} \mathrm{C}$ for $90 \mathrm{hrs}$; $\mathrm{e}-750{ }^{\circ} \mathrm{C}$ for $10 \mathrm{hrs} ; \mathrm{f}-750{ }^{\circ} \mathrm{C}$ for $90 \mathrm{hrs}$

The plasma spray coating could not withstand exposure to high-temperature for a prolonged period of time. There is an increased oxidation along the grain boundaries of the deposited splats with layer-shaped flaking of grains within the interface of oxide scale and aluminum layer after $90 \mathrm{hrs}$ at $750{ }^{\circ} \mathrm{C}$ both in dry air, Fig. $7 \mathrm{c}$, and in moist condition as in Fig. $7 \mathrm{f}$. Voids within the coating layer are also seen to increase both in size and number with cyclic exposure time and a little more in specimens under cyclic oxidation in moist conditions. In Fig. 3 through Fig. 6, although no signs of coating delamination were observed, degradation of the aluminum coating is much high in plasma spray coatings compared to hot-dip coatings. EDS analysis for elemental compositions taken along the $\mathrm{Y}-\mathrm{Y}$ axis of Fig. $7 \mathrm{~d}$ and $\mathrm{f}$ indicates that $\mathrm{Cr}, \mathrm{Fe}$ and $\mathrm{Ni}$ diffused outwards from the substrate to the surface of the coating as shown in Fig. 8 a and $b$ respectively. 


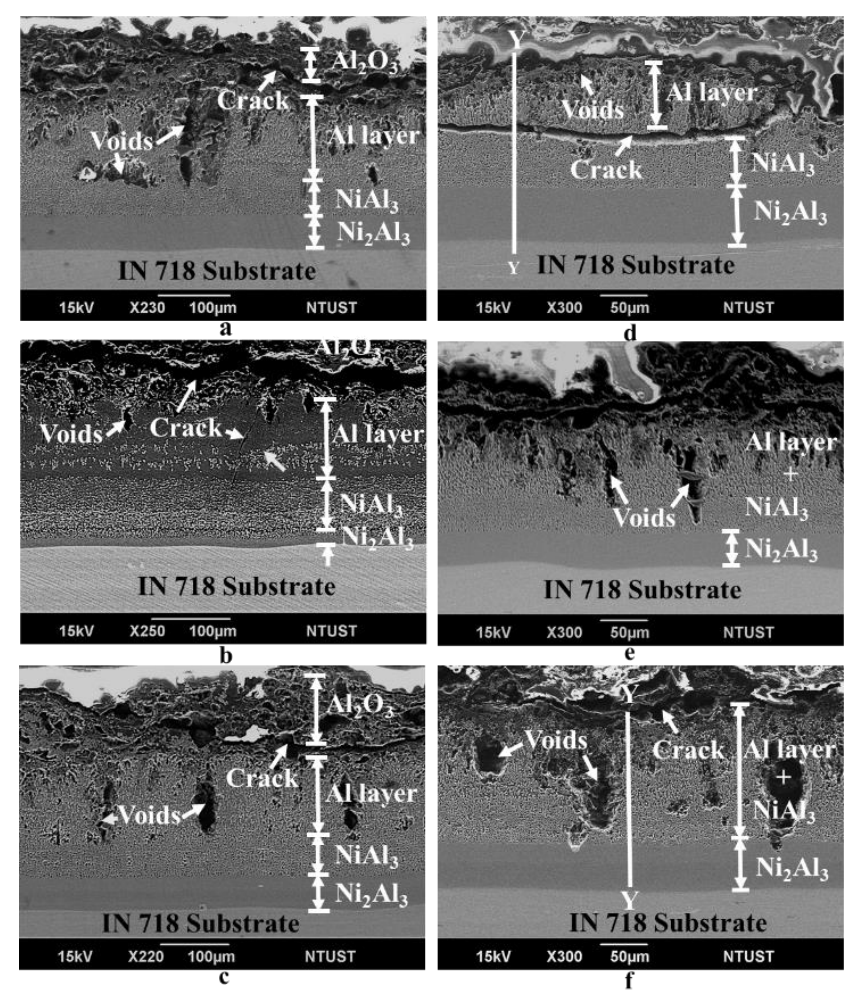

Fig. 7. Cross-sectional micrographs of plasma spray specimens oxidized in dry air at: $\mathrm{a}-650{ }^{\circ} \mathrm{C}$ for $90 \mathrm{hrs} ; \mathrm{b}-750{ }^{\circ} \mathrm{C}$ for $10 \mathrm{hrs} ; \mathrm{c}-750^{\circ} \mathrm{C}$ for $90 \mathrm{hrs}$, and in moist air at: $\mathrm{d}-650^{\circ} \mathrm{C}$ for $90 \mathrm{hrs}$; $\mathrm{e}-750{ }^{\circ} \mathrm{C}$ for $10 \mathrm{hrs} ; \mathrm{f}-750{ }^{\circ} \mathrm{C}$ for $90 \mathrm{hrs}$

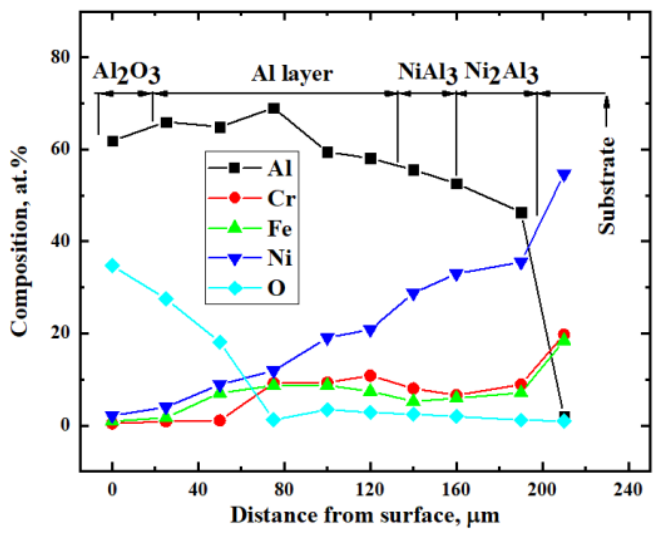

a

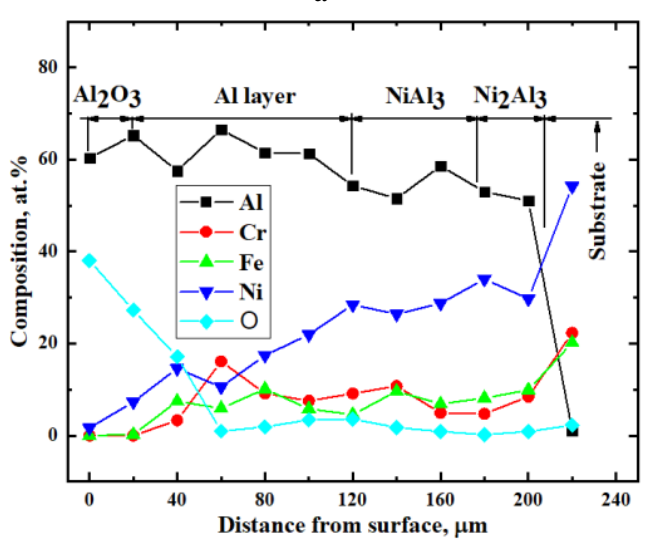

$\mathrm{b}$

Fig. 8. EDS results for elemental compositions $\mathrm{Al}, \mathrm{Cr}, \mathrm{Fe}, \mathrm{Ni}$ and $\mathrm{O}$ across the coating layer axis (Y-Y) after $90 \mathrm{hrs}$ in moist air for: a-Fig. $7 \mathrm{~d}$ at $650{ }^{\circ} \mathrm{C}$; b-Fig. $7 \mathrm{f}$ at $750{ }^{\circ} \mathrm{C}$

\section{DISCUSSION}

\subsection{Formation mechanism of the coating layer on IN 718 specimens}

According to experimental results, the as-deposited aluminized coatings consists of two layers in hot-dip and only one layer in plasma spray specimens shown in Fig. 1. The $1^{\text {st }}$ layer in hot-dip specimens shown in Fig. $1 \mathrm{a}$ is composed of aluminum phase and contains some dissolved nickel elements that were derived from the substrate. The $2^{\text {nd }}$ layer consists of $\mathrm{NiAl}_{3}$ - intermetallic phase formed beneath the aluminum layer. The formation mechanisms of the $\mathrm{NiAl}_{3}$ among other intermetallic phases within the coating layer can be discussed based on the knowledge of the binary phase formation for a given elements [5, 21]. An interface between liquid and solid exists during hot-dip process in which the aluminum is in molten state as liquid while nickel among other elements in the substrate are in solid state. As the coating process takes place, the $\mathrm{Ni}, \mathrm{Cr}$ and Fe from the IN 718 substrate dissolves and diffuses into the molten $\mathrm{Al}$ until the saturation level is reached then the extra atoms of elements such as $\mathrm{Ni}$ reacts with $\mathrm{Al}$ atoms to form intermetallic phase of $\mathrm{NiAl}_{3}$. The $\mathrm{NiAl}_{3}$ phase will then nucleate and grow in the supersaturated molten solution of $\mathrm{Al}$ near the interface forming a mixture of $\mathrm{NiAl}_{3}$ phase and Al solution. With continuous advancement of substrate elements mainly $\mathrm{Ni}$ among other minor elements into the molten aluminum solution, the growth of $\mathrm{NiAl}_{3}$ increases and continues to precipitates with increased hot-dip time. As the coated specimen is withdrawn from the aluminum molten solution allowing cooling and solidification to take place, the solubility of the substrate elements such as $\mathrm{Ni}$ in the Al solution is drastically reduced. The precipitation eventually takes place with the formation of a thin layer of $\mathrm{NiAl}_{3}$ phase at the interface as observed in Fig. 1 a. The formation of $\mathrm{NiAl}_{3}$ phase in the as-coated hot-dip specimens and absence of other phases such as $\mathrm{Ni}_{2} \mathrm{Al}_{3}$ attributes to complete consumption of $\mathrm{Ni}$ within the $\mathrm{Al}$ liquid solution. Thus, due to high surplus of $\mathrm{Al}$, only intermetallic compound of Ni-Al with higher $\mathrm{Al}$ content such as $\mathrm{NiAl}_{3}$ will form as seen in Fig. 1 [22]. Upon withdrawal from the molten bath, liquid aluminium due to surface tension effect solidifies to form a coating layer comprising of aluminide layer. Aluminum will also readily form oxides of $\mathrm{Al}_{2} \mathrm{O}_{3}$ upon withdrawal from molten metal due to its low free energy of oxide formation, thus the existence of alumina oxide [23].

The plasma spray as-coated specimen in Fig. $1 \mathrm{~b}$ consists of a single aluminum coating layer with existence of voids and pores. During plasma spray coating process, the atomized aluminum particles are oxidized forming entrapped oxides. With subsequent spray layer, existence of such oxides inhibits complete fusion of new aluminum splats to the already deposited one hence giving rise to presence of voids. Unlike hot-dip coating process where interdiffusion of elements takes place at the interface of coating and substrate, plasma spray coating which employ heat and velocity is characterized by near-zero dilution of the substrate due to mechanical bonding. Also, the substrate coated by plasma spray does not undergo any distortion, 
interdiffusion or metallurgical degradation compared with hot-dip coatings due to its low deposition temperatures.

\subsection{Effect of aluminum coatings on oxidation mechanism of IN 718 alloy}

Aluminium coatings showed the lowest oxidation rate in Fig. 2 after $90 \mathrm{hrs}$ cyclic oxidation as compared to bare substrate. Reduction in such mass change could be attributed to the formation of a more stable alumina oxide and intermetallic layer of $\mathrm{NiAl}_{3}$ as shown in Fig. 3 through Fig. 7 and illustrated in Fig. 9 a, which are reported to offer improved oxidation resistance. However, coatings oxidized in moist air slightly has a higher mass change. This could be likely as a result of the crack formation either on the surface scale or within the aluminium layer which allowed access of $\mathrm{H}_{2} \mathrm{O}$ to penetrate through paths of such cracks or voids. Reaction of $\mathrm{H}_{2} \mathrm{O}$ and aluminum forms an alumina oxide with increased mass gain [24, 25]. Nevertheless, the plasma spray coatings have slightly high mass gain than the hot-dip coating. Surface morphology of aluminized plasma spray coatings in Fig. 6 has irregular grain shapes with grooves, voids and cracks along the splat boundaries which increases the surface area for oxidation to take place, giving rise to high mass gain as observed. Such irregular grains also trap water vapour acting as oxidation sites. Illustration for initial oxidation of plasma spray coatings is given in Fig. $9 \mathrm{~d}$.

A continuous oxide layer of $\mathrm{Al}_{2} \mathrm{O}_{3}$ formed above a compact intermetallic and aluminum layers at $650{ }^{\circ} \mathrm{C}$ in dry air condition as given in Fig. 3 a for surface morphology and cross-sectional micrograph in Fig. 4 a. With increase in temperature, as in Fig. 3 b, c and Fig. 4 b, c at $750{ }^{\circ} \mathrm{C}$, protective nature of aluminum coating is reduced due to increased number of voids. The surface morphology depicted in Fig. 3 d, e has $\mathrm{Al}_{2} \mathrm{O}_{3}$ oxide scale debonding with existence of some cracks. Oxides such as $\mathrm{Al}_{2} \mathrm{O}_{3}$ are highly brittle and the cracks existing on the surface of the coated specimens are attributed to residual stress on such brittle oxides during rapid cooling [26]. When the aluminum alloy is used as a protective coating on IN 718, the intermetallic layer $\mathrm{NiAl}_{3}$ is not only consumed during interdiffusion for the growth of a brittle and less oxidation resistance phase such as $\mathrm{Ni}_{2} \mathrm{Al}_{3}$ but also for oxidation of itself. Oxidation of $\mathrm{NiAl}_{3}$ gives rise to oxides of $\mathrm{Al}_{2} \mathrm{O}_{3}, \mathrm{NiO}$ and spinels of $\mathrm{NiAl}_{2} \mathrm{O}_{4}$ as identified to exist in Fig. 3 through Fig. 6 with an illustration in Fig. 9 b, c. However, in moist condition as shown in Fig. 4 d, dissociation of water vapour into $\mathrm{OH}^{-}$and $\mathrm{H}^{+}$which in turn are incorporated into oxide lattice with formation of weak $\mathrm{Al}-\mathrm{OH}^{+}$bonds results to voids growth. Vacancy condensation due to fast outward diffusion of aluminum ions through the scale is reported to be the main reason for void formation in the oxide scale [23]. Such dissociation and void formation increases with temperature and oxidation duration as observed in Fig. 4. The dissociation of water vapour is also ascribed to weakening of the scale-alloy interfacial toughness thus promoting the formation of interfacial voids which accelerates spallation of the oxide scale with subsequent cracking of the coating $[27,28]$. Results of hot-dip coating in Fig. 4 indicates that the $\mathrm{Ni}-\mathrm{Al}$ intermetallic layers formed in the aluminum coating due to outward diffusion of nickel and not by inward diffusion of aluminum into the substrate. Such phenomenon is evidenced by EDS elemental line profile given in Fig. 5 indicating steady outward diffusion of substrate elements $\mathrm{Ni}, \mathrm{Cr}$ and $\mathrm{Fe}$ towards aluminum coating. The previous studies on oxidation of nickel-based superalloys with aluminium coatings also reported similar observation $[5,20,29]$. Conversely, degradation of the aluminum layer is due to inward diffusion of $\mathrm{Al}$ towards the substrate for the growth of $\mathrm{Ni}-\mathrm{Al}$ intermetallic layers and outward for growth of $\mathrm{Al}_{2} \mathrm{O}_{3}$. Depletion of such $\mathrm{Al}$ - contents are attributed to presence of Kirkendall voids in the coatings as illustrated in Fig. 9 b. Such voids in addition to presence of cracks within the coating layer acts as transport mechanism channel for oxidation of $\mathrm{NiO}$ and subsequent transformation into $\mathrm{NiAl}_{2} \mathrm{O}_{4}$ spinel as detected by EDS analysis [30]. The porous nature of $\mathrm{NiAl}_{2} \mathrm{O}_{4}$ spinel could further act as sites for internal oxidation and degradation of the aluminum layer as observed in Fig. $3 \mathrm{f}$ with illustration in Fig. 9 c. Spinel of $\mathrm{NiAl}_{2} \mathrm{O}_{4}$ phase though of porous nature is found to have high thermal and mechanical resistance as well as chemical stability finding application as catalyst support in various chemical reaction [31].

In plasma spray coatings, thermal stress generated during heating and cooling which are typical of aircraft gasturbine engines are attributed to cracks and voids observed in Fig. 7. The existence of mismatch between thermal expansion coefficients of the oxide scale, coating layers and the substrate are mainly ascribed as the cause of thermal stresses. Generation of such thermal mismatch stresses alternates between compressive and tensile stresses during thermal cycle resulting to crack initiation [32]. The cracksinitiated coalesce to form Kirkendall voids as seen in Fig. 7 with an illustration in Fig. 9 e. The coating layer further undergoes degradation due high susceptibility to cracking and spallation of $\mathrm{Al}_{2} \mathrm{O}_{3}$ oxide protective scale which is more brittle [26]. The inner layer is thus exposed for further fresh oxidation resulting to outward diffusion of aluminum giving rise to more Kirkendall voids formation which are found to increase with exposure duration as shown schematically in Fig. $9 \mathrm{f}$. Most of the porosities in the coating are reduced at $750{ }^{\circ} \mathrm{C}$ since most of the aluminium are in molten state thus reducing oxygen intake compared to specimens oxidized at $650{ }^{\circ} \mathrm{C}$ where most of the aluminum coating layer is in solid state allowing diffusion of more oxygen as observed in Fig. 8. Depletion of aluminum in the coating giving rise to formation of voids as observed during high-temperature exposure is therefore due to; (i) formation of $\mathrm{Al}_{2} \mathrm{O}_{3}$ oxide, (ii) inward diffusion for the growth of $\mathrm{NiAl}$-intermetallic layers, and (iii) formation of $\mathrm{NiAl}_{2} \mathrm{O}_{4}$ spinel. As observed in Fig. 2 through Fig. 7, hot-dip coatings have a better cyclic oxidation both in dry and moist air conditions compared to plasma spray coatings and bare specimens. Plasma spray coating failure could be attributed to presence of entrapped oxides and cracks arising during coating process. The hotdip coating on the other hand performed much better due to excellent adherent of the coating to the substrate with no observable voids, cracks or entrapped oxides.

\section{Acknowledgements}

Authors would like to acknowledge financial support of this research by the National Science Council, Taiwan under Grant No. NSC MOST105-2623-E-011-003-D. 

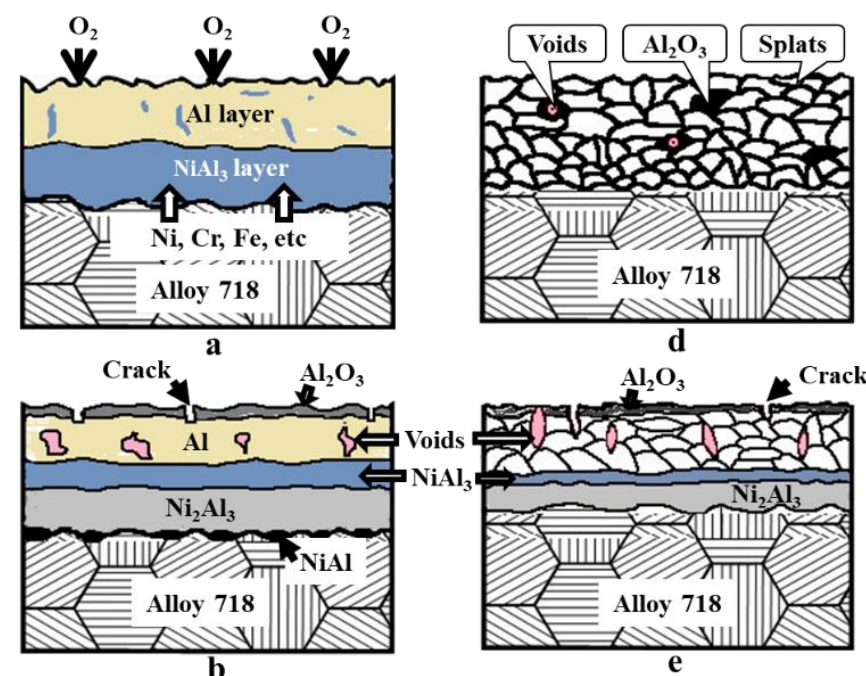

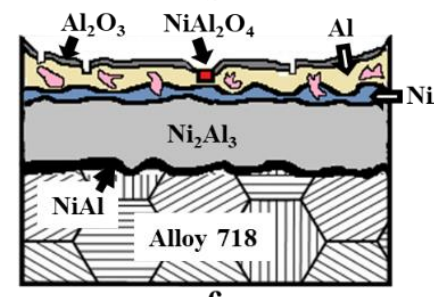

(i) Hot-dip aluminum

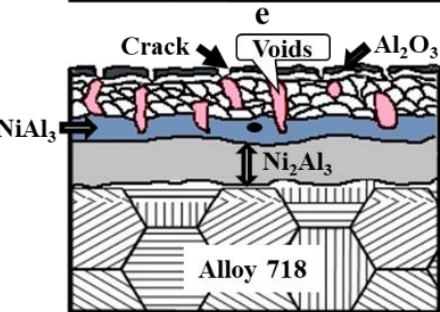

(ii) Plasma spray

Fig. 9. Schematic illustration of oxidation process on aluminized coated IN 718 in atm. air

\section{CONCLUSIONS}

Oxidation behavior and mechanisms of inconel 718 coated with aluminum alloy by hot-dip and plasma spray processes was conducted in dry and moist air conditions at different temperatures with exposure time of up to $90 \mathrm{hrs}$ to ascertain their performance. The findings of this study can be summarized as follows:

The hot-dip coatings greatly improved oxidation resistance of the alloy with lowest mass change compared to plasma spray and bare material.

The surface oxide layer formed on hot-dip coatings in dry air consists mainly of $\mathrm{Al}_{2} \mathrm{O}_{3}$ above the intermetallic aluminide layers of $\mathrm{NiAl}_{3}$ and $\mathrm{Ni}_{2} \mathrm{Al}_{3}$ whose thickness increased with duration of cyclic oxidation. However, voids in the aluminum layer increased at each thermal cycle causing depletion of aluminum in the coating with the formation of a porous $\mathrm{NiAl}_{2} \mathrm{O}_{4}$ spinel.

Moist air caused oxide scale formed in both types of aluminum coatings to crack after five cycles with extensive blistering and spallation. This could be attributed to hydrogen produced by reaction of water vapour with $\mathrm{Al}$ or $\mathrm{Ni}$ to dissolve in the alloy but released on cooling causing the oxide to blister or spall.

Aluminum coatings are more porous with profound internal voids in moist air. However, water vapour did not appear to cause large effects on hot-dip coating as compared to plasma spray coating.

Thus, it was concluded that hot-dip coating has a better oxidation resistance to improve performance of IN 718 at high temperature applications both in dry and moist air conditions compared to plasma spray coating.

\section{REFERENCES}

1. Al-hatab, K.A., $\quad$ Al-bukhaiti, M.A., $\quad$ Krupp, U., Kantehm, M. Cyclic Oxidation Behavior of IN 718 Superalloy in Air at High Temperatures Oxidation of Metals 75 (3-4) 2011: pp. 209-228. https://doi.org/10.1007/s11085-010-9230-6

2. Zhang, Y.N., Cao, X., Wanjara, P., Medraj, M. Oxide Films in Laser Additive Manufactured Inconel 718 Acta Materialia 61 (17) 2013: pp. 6562-6576. https://doi.org/10.1016/j.actamat.2013.07.039

3. Mudgal, D., Singh, S., Prakash, S. Cyclic Hot Corrosion Behavior of Superni 718, Superni 600, and Superco 605 in Sulfate and Chloride Containing Environment at $900{ }^{\circ} \mathrm{C}$ Metallography, Microstructure, and Analysis 4 (1) 2015: pp. $13-25$. https://doi.org/10.1007/s13632-014-0182-0

4. Mannava, V., Rao, A.S., Paulose, N., Kamaraj, M., Kottada, R.S. Hot Corrosion Studies on Ni-Base Superalloy at $650{ }^{\circ} \mathrm{C}$ Under Marine-Like Environment Conditions Using Three Salt Mixture $\left(\mathrm{Na}_{2} \mathrm{SO}_{4}+\mathrm{NaCl}+\mathrm{NaVO}_{3}\right) \quad$ Corrosion Science 105 2016: pp. 109-119. https://doi.org/10.1016/j.corsci.2016.01.008

5. Davis, J.R. ASM Specialty Handbook, Nickel, Cobalt and Their Alloys. 2000, ASM International. pp. 1-186.

6. Chaturvedi, M.C., Han, Y.F. Strengthening Mechanisms in Inconel 718 Superalloy Metal Science 17 (3) 1983: pp. $145-149$. https://doi.org/10.1179/030634583790421032

7. Sundararaman, M., Mukhopadhyay, P., Banerjee, S., Some Aspects of the Precipitation of Metastable Intermetallic Phases in INCONEL 718 Metallurgical Transactions A 23 (7) 1992: pp. 2015-2028. https://doi.org/10.1007/bf02647549

8. Cozar, R., Pineau, A. Morphology of $\gamma^{\prime}$ and $\gamma^{\prime \prime}$ Precipitates and Thermal Stability of Inconel 718 Type Alloys Metallurgical Transactions 4 (1) 1973: pp. 47-59. https://doi.org/10.1007/bf02649604

9. Jianhong, H., Fukuyama, S., Yokogawa, K. $\gamma^{\prime \prime}$ Precipitate in Inconel 718 Journal of Material Science Technology 10(4) 1994: pp. $293-303$.

10. Bi, Z.N., Dong, J.X., Zhang, M.C., Zheng, L., Xie, X.S. Mechanism of $\alpha-\mathrm{Cr}$ Precipitation and Crystallographic Relationships Between $\alpha-\mathrm{Cr}$ and $\delta$ Phases in Inconel 718 Alloy After Long-Time Thermal Exposure International Journal of Minerals, Metallurgy, and Materials 17 (3) 2010: pp. $312-317$.

https://doi.org/10.1007/s12613-010-0310-z

11. Mahobia, G.S., Paulose, N., Singh, V. Hot Corrosion Behavior of Superalloy IN718 at 550 and $6500^{\circ} \mathrm{C}$ Journal of Materials Engineering and Performance $22(8)$ 2013: pp. $2418-2435$. https://doi.org/10.1007/s1 1665-013-0532-0

12. Saladi, S., Menghani, J., Prakash, S. Hot Corrosion Behaviour of Detonation-Gun Sprayed $\mathrm{Cr}_{3} \mathrm{C}_{2}-\mathrm{NiCr}$ Coating on Inconel-718 in Molten Salt Environment at $900{ }^{\circ} \mathrm{C} T$ Indian I Metals 67 (5) 2014: pp. 623-627. https://doi.org/10.1007/s12666-014-0383-x

13. Slama, C., Servant, C., Cizeron, G., Aging of the Inconel 718 Alloy Between 500 and $750{ }^{\circ} \mathrm{C}$ Journal of Materials Research 12 (09) 2011: pp. 2298-2316. https://doi.org/10.1557/jmr.1997.0306

14. Zurek, J., Young, D.J., Essuman, E., Hänsel, M., Penkalla, H.J., Niewolak, L., Quadakkers, W.J. Growth and Adherence of Chromia Based Surface Scales on Ni-Base 
Alloys in High- and Low-pO $\mathrm{p}_{2}$ Gases Materials Science and Engineering: A $477(1-2)$ 2008: pp. 259-270. https://doi.org/10.1016/j.msea.2007.05.035

15. Wang, C.J., Chen, S.M. Microstructure and Cyclic Oxidation Behavior of Hot Dip Aluminized Coating on NiBase Superalloy Inconel $718 \quad$ Surface \& Coatings Technology 201 (7) 2006: pp. 3862-3866. https://doi.org/10.1016/j.surfcoat.2006.07.242

16. Chen, J.H., Little, J.A. Degradation of the Platinum Aluminide Coating on CMSX4 at $1100{ }^{\circ} \mathrm{C}$ Surface \& Coatings Technology $92(1-2)$ 1997: pp. 69-77. https://doi.org/10.1016/S0257-8972(96)03117-9

17. Visuttipitukul, $P$., Limvanutpong, N., Wangyao, $P$. Aluminizing of Nickel-Based Superalloys Grade IN 738 by Powder Liquid Coating Materials Transactions $51(5)$ 2010: pp. $982-987$. https://doi.org/10.2320/matertrans.M2009382

18. Zagula-Yavorska, M., Kubiak, K., Sieniawski, J. Oxidation Behaviour of Palladium Modified Aluminide Coatings Deposited by CVD Method on Nickel-Based Superalloys Under Air Atmosphere Journal of Achievements in Materials and Manufacturing Engineering $55(2)$ 2012: pp. $848-854$.

19. Cheng, W.J., Wang, C.J. Effect of Chromium on the Formation of Intermetallic phases in Hot-dipped Aluminide Cr-Mo Steels Applied Surface Science 277 2013: pp. $139-145$. https://doi.org/10.1016/j.apsusc.2013.04.015

20. Zielinska, M., Sieniawski, J., Yavorska, M., Motyka, M. Influence of Chemical Composition of Nickel Based Superalloy on the Formation of Aluminide Coatings Archives of Metallurgy and Materials 56 (1) 2011: pp. $193-197$. https://doi.org/10.2478/v10172-011-0023-y

21. ASM-International, ASM Handbook: Volume 3: Alloy Phase Diagrams. 1992, Materials Park, Ohio: ASM International.

22. Jiang, S.Y., Li, S.C. Formation Mechanism and Prediction of New Phases in Binary Metallic Liquid/Solid Interface Rare Metals 30 (S1) 2011: pp. 486-491. https://doi.org/10.1007/s12598-011-0330-5

23. Birks, N., Meter, G.H., Pettit, F.S. Introduction to the HighTemperature Oxidation of Metals. 2006, Cambridge University Press: United States of America. pp. 352.

24. Chevalier, S., Juzon, P., Przybylski, K., Larpin, J.P. Water Vapor Effect on High-Temperature Oxidation Behavior of
$\mathrm{Fe}_{3} \mathrm{Al}$ Intermetallics Science and Technology of Advanced Materials 10 (4) 2009: pp. 1-7.

https://doi.org/10.1088/1468-6996/10/4/045006

25. Rouaix-Vande Put, A., Unocic, K.A., Brady, M.P., Pint, B. A., Performance of Chromia- and Alumina-Forming Fe- and Ni-Base Alloys Exposed to Metal Dusting Environments: The Effect of Water Vapor and Temperature Corrosion Science 92 2015: pp. 58-68. https://doi.org/10.1016/j.corsci.2014.11.022

26. Stott, F.H. The Protective Action of Oxide Scales in Gaseous Environments at High Temperature Reports on Progress in Physics 50 (7) 1987: pp. 861-913. https://doi.org/10.1088@0034-4885@50@7@002

27. Wang, C.J., Badaruddin, M. The Dependence of High Temperature Resistance of Aluminized Steel Exposed to Water-Vapour Oxidation Surface and Coatings Technology 205 (5) 2010: pp. 1200-1205. https://doi.org/10.1016/j.surfcoat.2010.08.153

28. Yan, K., Guo, H., Gong, S. High-Temperature Oxidation Behavior of $\beta$-NiAl With Various Reactive Element Dopants in Dry and Humid Atmospheres Corrosion Science 83 2014: pp. $335-342$. https://doi.org/10.1016/j.corsci.2014.02.033

29. Goward, G.W., Boone, D.H. Mechanisms of Formation of Diffusion Aluminide Coatings on Nickel-Base Superalloys Oxidation of Metals 3 (5) 1971: pp. 475-495. https://doi.org/10.1007/bf00604047

30. Zygmuntowicz, J., Wiecińska, P., Miazga, A., Konopka, K. Characterization of Composites Containing $\mathrm{NiAl}_{2} \mathrm{O}_{4}$ Spinel Phase from $\mathrm{Al}_{2} \mathrm{O}_{3} / \mathrm{NiO}$ and $\mathrm{Al}_{2} \mathrm{O}_{3} / \mathrm{Ni}$ Systems Journal of Thermal Analysis and Calorimetry 125 (3) 2016: pp. $1079-1086$. https://doi.org/10.1007/s10973-016-5357-2

31. Anchieta, C.G., Tochetto, L., Madalosso, H.B., Sulkovski, R.D., $\quad$ Serpa, C., $\quad$ Mazutti, M.A., de Almeida, A.R.F., Gündel, A., Foletto, E.L. Effect of Thermal Treatment on the Synthesis of $\mathrm{NiAl}_{2} \mathrm{O}_{4}$ Spinel Oxide Using Chitosan as Precursor Cerâmica 61 (360) 2015: pp. $477-481$. https://doi.org/10.1590/0366-69132015613601925

32. Thouless, M.D. Cracking and Delamination of Coatings Journal of Vacuum Science \& Technology A: Vacuum, Surfaces, and Films 9 (4) 1991: pp. 2510-2515. https://doi.org/10.1116/1.577265 